\title{
0 eu no design: entrevista com Maria Dolores
}

\section{[VIRGINIA BORGES KISTMANN]}

Programa de Pesquisa e Pós-Graduação em Design da Universidade Federal do Paraná. Doutora em Engenharia de Produção pela Universidade Federal de Santa Catarina, com programa sanduiche na Köln International School of Design: Kisd (Alemanha).

email: vkistmann@gmail.com 


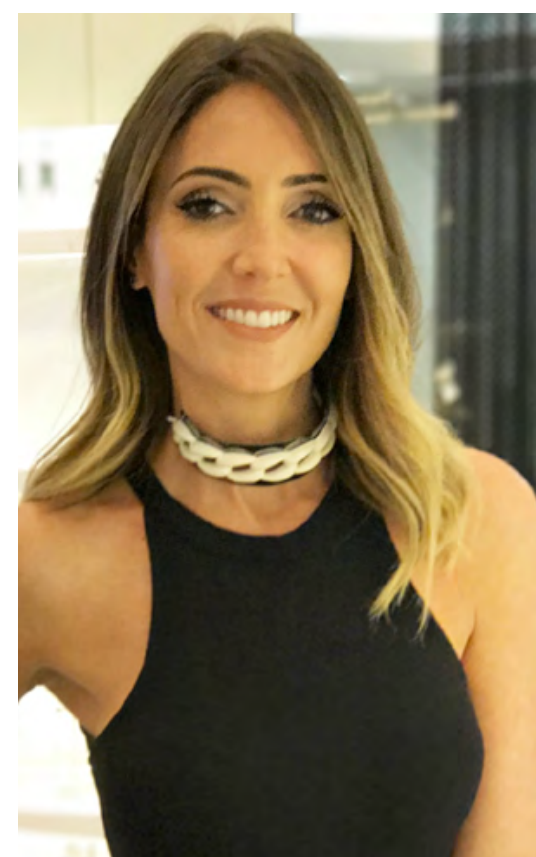

Figura 1: Designer de joias Maria Dolores Gasparin.

Maria Dolores Gasparin é proprietária da grife Maria Dolores' ${ }^{1}$ com sede em Curitiba. A marca tem 9 anos e traz como caracteristicas principais em suas coleções a busca por novas soluções conceituais a partir de estudo de materiais e uma linguagem alinhada à pesquisa de tendências.

Em seus produtos, loja e nos elementos de comunicação ficam evidentes as caracteristicas de uma gestão de design eficaz. Verifica-se também as parcerias com designers de moda e a participação em eventos da área. A designer justifica a adoção do termo joia para suas peças, embora não use metais nobres ou pedras preciosas em suas criações, pelo alto valor agregado que estas possuem. Esses fatores, considerados importantes no design de moda e acessórios, provocaram o interesse na evolução da marca, levando à entrevista apresentada aqui, desenvolvida a partir de três momentos: ontem, hoje e amanhã.

Percebe-se, na fala de Maria Dolores, a importância de sua personalidade, que se reflete na condução da marca ao longo dos anos. A sua veia empreendedora e o suporte dado pelo marido contribuíram para o seu sucesso. Maria Dolores associa design e arte e produz conceitos inovadores no campo da moda.

Conte-me um pouco sobre a sua história e como você chegou à Maria Dolores de hoje.

Eu nasci em Curitiba, em 1979. Aos 5 anos, comecei o maternal. Minha mãe é bem sensivel, e sentindo que eu já tinha uma ligação com a arte, me matriculou em um colégio que incentivava muito a criatividade. Nessa escola não havia brinquedos, eles eram criados com sucata. Então, desde pequenininha, fui estimulada para a criação. Depois fui para o colégio marista Santa Maria, aqui em Curitiba, cidade de onde nunca saí. Minha mãe é de Ponta Grossa (PR), meu pai é mineiro, e eles moram em Curitiba há muitos anos.

No vestibular, eu fiz prova para o curso de Desenho Industrial. Na verdade, eu fiz Desenho Industrial porque achei que teria a ver com desenho. Eu acho que nessa fase, 16, 17 anos, a gente acaba não se informando tanto. Eu era mais interessada nas Belas Artes, mas fui para o Desenho Industrial porque tinha vontade de desenhar móveis. 
Eu ainda não tinha certo de que era com moda que queria trabalhar, embora sempre gostasse muito de moda, acompanhava desfiles, gostava de me vestir de uma forma diferente etc. Não achei que fosse trabalhar com isso. Ainda não estava muito certa com 17 anos.

Eu entrei na Universidade Federal do Paraná (UFPR) em 1997. E fui percebendo que o curso era muito voltado para as máquinas, as ferramentas. Por isso, muitas pessoas do meu grupo desistiram no meio do curso. Durante o primeiro ano, experimentei a área de design de móveis, trabalhei e fiz estágio em um escritório de arquitetura. Depois, tentei Design Gráfico. Trabalhei em agência de publicidade, sempre como estágio. Foi onde eu aprendi os cursos de computação que sei hoje.

Do segundo para o terceiro ano da faculdade, eu comecei a criar algumas bijuterias para mim. Não tinha a ver com o curso de Desenho Industrial. Eu ia bem na faculdade, mas nada do que estava aprendendo ali queria levar para a minha vida. Então, comecei a fabricar algumas bijuterias e customizava roupas. Eu fazia tudo que era ligado à moda. Mas para mim, não para vender.

Algumas amigas fashionistas, que gostavam das peças, pediam para eu criar para elas. Fui criando: não só para as amigas, mas para as amigas delas. Minhas amigas começaram a solicitar mais e, aos pouquinhos, fui comprando peças e montando mais bijuterias, até que resolvi vendê-las. Algumas amigas perguntaram se podiam vender minhas peças. Fui aumentando a produção e pensei: é uma boa!

Com uma colega do curso de Desenho Industrial, montei um pequeno escritório para fazer perspectiva 3D para arquitetos. Eu tinha aprendido computação gráfica na faculdade. Mas, paralelo a isso, fazia minhas bijuterias.

Só que eu comecei a gostar muito dessa brincadeira. Ficava madrugadas e madrugadas montando os itens. Comprava pecinhas na Rua 25 de Março e a minha produção foi aumentando, aumentando, aumentando.

Primeiro, eu me juntei com duas amigas e montamos uma marca que se chamava Catarina Cassilda. Mas elas seguiram outros caminhos. Dai, continuei sozinha. Até quando participei de um bazar em que expus o meu trabalho. Nele, uma pessoa que trabalhava no marketing da joalheria Bergerson, de Curitiba, me falou: "Achei muito interessante o seu trabalho. Você não gostaria de fazer uma entrevista? De repente, você pode seguir o rumo das joias, não?".

Eu estava no quarto ano da faculdade e fui fazer esse teste. Eu não tinha noção do material, ouro ou pedras preciosas, porque meu negócio era montagem. Mas marquei uma entrevista. Então, o Marcelo, o diretor da Bergerson, me deu um mês para eu me preparar e apresentar algum material. Ele queria uma pessoa jovem para a joalheria atingir um público também mais jovem. Joias com um valor um pouco mais baixo do que eles vendiam, com design mais moderno. Fui fazer cursos de ourivesaria, gemologia ou o que encontrava. Com isso, apresentei uma proposta que eles gostaram e me contrataram.

Fiquei na Bergerson por quatro anos, o que considero que foi a minha faculdade. Durante esse tempo, pude fazer um curso de ourivesaria, para aprender e acompanhar a produção no ateliê dos ourives, de quem fiquei muito amiga. Com eles, participava das feiras.

Estava com 21, 22 anos quando entrei na empresa e foi uma oportunidade muito bacana trabalhar na melhor joalheria do Paraná, eu aprendi bastante 
com pessoas que tinham uma experiência enorme, uma bagagem grande, $E$ eu era bem feliz, gostava de trabalhar lá e me dava bem com todo mundo. Porém, no último ano, a vontade de ter o meu negócio (eu tenho essa coisa meio empreendedora) aflorou.

Depois de casar, passei um semestre com o meu marido na Itália. A gente queria fazer cursos, dar um tempo, ver o que fazer da vida. Nesse período, eu me especializei em joalheria. Fiz cursos de técnicas, cera, modelagem e modelagem 3D em duas escolas: Metallo Nobile e Le Arti Orafe, em Florença. Quando voltamos, montei a minha loja no Shopping Crystal, pois eu queria ter uma marca própria.

Antes de ir para a Itália, eu já tinha feito testes com fornecedores. Entre sair da Bergerson e ir para a Itália, tive seis meses. Eu já estava meio certa de que queria trabalhar com alguma coisa que não era joia, nem bijuteria. Seria uma semijoia.

Eu não gosto do termo semijoia, mas não acho nenhum outro que realmente explique, defina, o que crio. Por isso, digo que o que eu faço é design de joias, meu produto é uma joia. Existe a definição que muitos usam: só com metais nobres e pedras preciosas. Mas, para mim, joias são adornos que deixam a mulher bonita, independentemente do material utilizado.

Às vezes, quando você fala em joias, as pessoas ficam com a dúvida: "Será que vou ali? Não vou naquela loja para conhecer porque tudo deve custar muito caro". Como são peças grandes, se eu falar que são joias, as pessoas são capazes de achar que vão custar uma fortuna. Mas, enfim, voltando à loja do 2I4 ] Shopping Crystal, foi muito bacana porque, na verdade, ela foi a realização de um sonho, porque eu não fiz nenhum estudo.

\section{0 seu TCC foi na área de joias?}

Em móveis. Na verdade, móveis com tecnologia. Não eram bem móveis, eram objetos. A gente tinha que fazer o cadeira que tivesse algum diferencial e, então, em um dos objetos, eu trabalhei a madeira de uma maneira que não tivesse junções. Foi um trabalho feito junto com o marceneiro. Outro objeto foi um computador infantil de acrílico. Nada a ver com acessórios, joias.

A atividade na Bergerson teve repercussão na sua graduação? Ou você terminou a faculdade e depois entrou na Bergerson?

Eu trabalhava, fazia estágios, enquanto estudava. E se alguma matéria contribuiu para a minha carreira foi História da Arte. Acho que o meu curso foi muito fraco, não sei se eu não estava na mesma vibração, e achei que ele era muito técnico.

Eu sempre gostei de arte. Então, quem sabe por eu estar ligada à arte, de repente, em algum momento ou outro, eu a introduzi nas minhas coleções. Eu já havia feito um curso básico de História da Arte, e de todas as técnicas de pintura. Depois, fui voltando mais para tecnologia. Na verdade, esses foram pontos positivos para entrar na Bergerson. Porque ninguém trabalhava lá com design digital. Tudo era feito à mão. Eles queriam dar uma modernizada. Quando eu apresentei os desenhos feitos no computador, acho que teve um peso. Querendo ou não, alguns desses cursos eu tive na faculdade. 


\section{E a loja do Shopping Crystal?}

Ela realmente foi a realização de um sonho. Tive muita ajuda financeira do meu marido e dos meus pais para montá-la. Eu não fiz estudo de mercado e não analisei se o Crystal era o melhor local para a loja.

Eu tenho uma intuição forte, acredito muito nela, e tudo caminhou para ser desse jeito. Eu tenho muita confiança no meu trabalho. Tenho um sexto sentido, acredito. E eu não faço nada por acaso.

Antes de lançar a coleção, eu pensei muito para não dar errado. Claro que já cometi alguns erros no passado. Hoje, a gente já entende o porquê. Eles já não acontecem mais. Mas, desde o início, eu tive essa segurança. Acreditava que ia dar certo porque não tinha aquele tipo de produto no mercado. Sempre existiu semijoia, mas eu queria trazer uma nova maneira de fazê-la, um olhar diferente, mais moderno.

Então, eu queria trazer uma inovação para o acessório. Queria que ele não fosse uma bijuteria baratinha, descartável, mas também que não fosse uma joia. Que estivesse no meio termo. Para aquela mulher que adora moda e gosta de variar. Que possa comprar com frequência e estar sempre fashion. E tive uma aceitação muito boa, desde o início, a loja caminhou bem.

Depois de seis meses, estava quase ficando louca porque eu fazia tudo: desenhava, administrava, contratava, demitia, lidava com o fornecedor. Estava pirando. Foi quando o meu marido perguntou: quanto você faturou nesses seis meses? Eu não sabia responder porque a parte financeira estava totalmente desorganizada. Então, ele falou: "Isso não pode! Você tem que estar com tudo alinhado senão as coisas vão desandar". Então, ele trouxe uma funcionária dele para organizar a vida financeira e administrativa do negócio. Essa funcionária foi gostando muito de trabalhar na nova área, tanto é que ela está comigo até hoje. Ela é nosso braço direito. E com ele cuidando tanto da parte administrativa financeira como da expansão, as coisas foram acontecendo, porque ele tem uma visão empreendedora. Assim, a gente formatou uma franquia. Eu, naquele momento, só tinha uma loja e vivia de sonhos, me sentia realizada fazendo aquilo. Então, com a ajuda do meu marido, tudo deu muito certo. A marca completa 9 anos em 2017 e já são nove lojas.

Você disse que seu pai e sua mãe ajudaram no começo. Eles têm alguma formação na área de arte, de joias? São empresários?

0 meu pai é engenheiro. Agora se aposentou. A minha mãe é formada em Letras. Foi professora, trabalhou sempre com línguas, mas era mais dona de casa, se dedicando aos filhos. Ela sempre gostou de arte. Os dois gostam. Eles me ajudaram porque sabiam que a loja era o meu sonho e acreditavam em mim. Então, eles investiram nesse meu sonho, me deram uma chance. E eu fui trabalhando.

Então, no início, qual era o conceito que você tinha da loja, o que curtia fazer?

Eu tinha 28 anos e, na verdade, o que eu gosto de fazer não mudou. Por mim, eu só faria peças conceituais, artísticas, essas que vêm mais de dentro, sem pensar muito no lado comercial. 0 que aprendi nesse processo de amadurecimento, durante nove anos, foi equilibrar muito bem o conceitual com o comercial, esses dois mundos. 
Eu tenho que saber por que as pessoas vêm até mim, por que querem a minha marca. É porque ela é diferente, mas é usável, é viável e é possivel pagar por ela. Eu estou propondo um negócio diferente: a peça confortável, e não vou descartá-la no mês que vem porque vai cair de moda ou alguma coisa assim.

Então, eu procuro sempre equilibrar isso. Preciso vender, mas não posso fazer só o básico. Eu tenho que trazer o design, que é o DNA da marca. A caracteristica principal é justamente essa exclusividade.

Eu gosto de surpreender as pessoas com o meu design. E isso realmente é um desafio. Gosto muito de fazer peças conceituais que vão sendo lapidadas até virarem básicas, por questão de preço, tamanho, conforto. Eu agora consigo trazer um pouco mais de conceito às criações, o que eu não conseguia no começo. Como a marca era nova, eu precisava muito que ela desse lucro, caminhasse. Tinha que fazer muita peça básica para ter retorno financeiro. Aos poucos, fui introduzindo mais e mais e mais conceito até chegar ao que a marca é hoje.

As pessoas já sabem que, na loja, elas vão encontrar produtos diferentes, que não há nada parecido na loja ao lado. Quando alguém quer dar um presente surpreendente, quando quer usar uma joia diferente em uma festa, sabe que vai encontrar na minha loja. Mas eu nunca tive uma orientação de como criar uma coleção. Fiz do jeito que eu imaginava que iria funcionar. Sempre!

Seu marido foi ajudá-la, e você tinha uma pessoa fazendo a parte financeira...

Algumas pessoas vieram para ajudar. Outras se interessaram pelo produto e quiseram revendê-lo. Tiveram sucesso, e são minhas franqueadas. Eu fico feliz porque todas as minhas franqueadas são pessoas que realmente amam a marca. Elas têm prazer imenso e orgulho em trabalhar com esse produto. São pessoas realmente parceiras. É uma delícia, a cada coleção, ver a alegria delas! Então, para mim, realmente é uma realização. Mas foi passo a passo, sabe? Tirando a primeira loja, que não foi planejada, depois, com a ajuda dos que vieram a gente teve uma aceitação muito boa nas demais. Todo mundo fala que Curitiba é uma cidade difícil, mas para mim não foi. Então, eu agradeço a cidade que me abraçou, que abraçou meu trabalho.

Eu era muito ansiosa, mas não sou mais. Agora, eu até prefiro que leve mais tempo para as coisas acontecerem, mas que aconteçam de forma concreta. Mais do que uma loucura que vai embora. 0 meu marido, Neto, é muito certinho, tem uma visão de negócio muito boa.

\section{Ele tem formação em marketing?}

Ele é engenheiro civil. A minha primeira loja foi a do Crystal. Depois, abrimos no Barigui, e vieram as lojas de Londrina e Maringá. Em Londrina, tivemos um problema com o shopping e resolvemos fechar. A loja de Maringá continua e vai muito bem. Depois, veio Goiânia: com cinco anos, é um dos nossos grandes exemplos, é uma das melhores lojas. A franqueada é uma pessoa que respira a marca. É lindo de ver! Ela realmente inspira. Vieram Vitória e São Paulo, com três anos e loja própria. E em maio do ano passado, abrimos a nossa primeira franquia internacional, em Barcelona.

Essa loja começou a abrir frentes no atacado e está começando a vender para outros paises, exportando por lá. É uma vitrine para o mundo e está 
abrindo muitas portas, com oportunidades legais que estão no forno. Agora, em 2017, o foco está totalmente voltado para o mercado internacional.

Estamos crescendo na parte de revendas. Hoje são mais de 70 revendedoras no Brasil, atendendo 25 estados. E o atacado vai bem. Claro que se aparecerem novos parceiros para franquia, vamos gostar muito. Mas estamos muito voltados para o internacional porque sentimos uma aceitação muito boa lá fora. E tem grandes chances de negócio para a marca. Isso é maravilhoso.

\section{Como é o seu processo de trabalho?}

Eu sou bem observadora, estou sempre com o radarzinho ligado. No ano passado, fui para Barcelona, na inauguração da loja. Depois, fui para lbiza. $\mathrm{E}$ pensei: nossa, nada me inspirou! Não tem nenhuma observação, não anotei nada no meu moleskine (eu sempre ando com os meus moleskines e canetas, para anotar alguma referência, alguma coisa). Quando voltei, comecei a desenhar uma coleção que era a cara de lbiza, e virou a minha coleção de fim de ano. Quero dizer que as referências, de certa forma, ficaram guardadinhas ali. $\mathrm{Na}$ hora que eu resolvi montar a coleção, afloraram.

Eu acho que isso acontece muito comigo. E cada hora é de um jeito. Às vezes, eu vou a um lugar, uma exposição, um evento, em que tudo me chama a atenção. $E_{1}$ assim, eu já começo a bolar a coleção ali mesmo. Quando vem, eu já desenho e brota. E às vezes não, fica guardado. Algumas referências, meses depois, acendem uma luzinha assim, sabe? Eu adoro livros de arte. Tenho vários. Sempre busco referência neles, na internet, no streetstyle, nas semanas de moda. Acabo pegando algum formato, alguma textura, alguma coisa.

Então, você é antenada no que está acontecendo no mundo da moda? Você é bem conectada?

Com tudo! Eu sou bastante conectada, eu tinha até que desconectar um pouco, mas não consigo.

\section{Você vai a desfiles?}

Vou nos que eu consigo. Eu tento. Porque não ir (acho que a moda está em São Paulo, no Rio ou em cidades como Nova York, Paris, Londres) acaba limitando um pouco a criação. Mas eu sou mãe, tenho dois filhos e sou bem ligada à minha família. Eu me estruturei de uma forma que, de manhã, fico voltada para a casa mesmo. Então, levo as crianças para a escola, vou buscá-las. Todos os dias, faço todas as refeições com os meus filhos: café da manhã, almoço e jantar. Claro, só quando eu viajo que não! Eu consegui montar uma estruturinha para que eles fiquem bem quando eu não estou. Eu sou bem família, sou bem mãezona. Então, isso acaba me privando de estar em alguns eventos importantes da minha área. Mas, hoje em dia, graças a Deus, a internet me permite não ficar tão afastada. Eu só não estou presente, mas acompanho o que está acontecendo.

Você, normalmente, tem ideias, elabora os esboços, faz os desenhos e depois? Quando começa a escolha dos materiais? Você vai buscá-los ou já os tem quando cria?

Às vezes. Cada coleção acontece de uma forma, não tenho muito um padrão, uma receita. Eu começo desenhando, geralmente, um brinco. Nor- 
malmente, essa é a minha primeira peça. Não sei porque, mas é. Oitenta por cento das coleções nascem de um brinco. E ai eu vou desenrolando: a partir de uma peça, crio outros itens.

E quando eu escolho um tema, uma inspiração, já tenho alguma coisa na minha cabeça em relação a cores, materiais, pedras. Claro que no processo da criação, muitas vezes, eu vou mudando, mas sempre há uma ideia inicial. E eu gosto de fazer uma mistura de materiais. Gosto de colocar couro, tecido, madeira e de misturar pedras.

Eu vi que você experimenta muito.

Sim, eu gosto.

Como isso acontece? É algo que leva muito tempo ou você tem facilidade para resolver por conhecer bem os materiais?

Geralmente, entre desenhar a coleção e ela chegar às lojas, são cinco ou seis meses de processo. Já aconteceu de, por exemplo, eu ter sido convidada para fazer uma semana de moda em parceria com uma estilista e ter que apresentar a coleção em três dias para o timing da produção dar certo.

Então, sob pressão, eu também funciono bem, só preciso estar bastante concentrada e em um momento de paz. E se eu me fechar, em três dias brotam as ideias. Eu geralmente não gosto muito de trabalhar sob pressão porque acabo colocando uma energia muito forte no que estou fazendo. Mas é muita, mesmo! Quando criei a coleção em três dias, tive todas as "ites": cistite, amigdalite, bronquite... Baixou a imunidade no chão. Realmente, é um pouco tenso. É mesmo uma demanda de energia, como se eu tivesse feito uma superginástica, mas mental. A coisa vem de dentro. Por isso, fiquei doente, pelo esforço.

0 resultado foi maravilhoso, uma das coleções mais lindas. Foi a minha coleção do inverno do ano passado. Ela virou um clássico. Quando falamos isso, significa que essas peças vão virar eternas na marca. Sempre haverá pedidos, tem demanda para isso. E é uma coleção que teve uma exposição muito grande na mídia. É bem especial para mim. Muito, muito! Uma das mais. Então, as mais difíceis são as que eu mais gosto.

Tem outra que se chama U-rock, uma coleção com pedras brutas, não lapidadas. Elas são marteladas, e para martelar e deixar uma peça igual ou parecida com a outra foi um trabalho muito, muito, muito grande, que envolveu muitas pessoas. Essa é uma coleção pela qual eu também tenho um carinho enorme. Mas cada uma eu faço de um jeito.

Você tem uma equipe própria de confecção ou é terceirizada?

Terceirizo e confecciono. Alguns moldes são feitos aqui, mas a maioria é terceirizada. E são diversos fornecedores.

\section{Isso porque você tem muitos acabamentos?}

Às vezes, as peças viajam por algumas fábricas até chegarem ao produto final. Por isso, leva-se tanto tempo. E requer uma atenção e um controle de qualidade muito grande porque, por mais que eu agora tenha várias lojas, com tudo feito em série, o negócio é manual no colar a pedra, lapidar um a um. 
Como controla a produção? Porque, se você está terceirizando, pode haver erros. 0 controle é feito pelo fornecedor, por fornecedor ou, quando recebe as peças, você mesma o faz?

Nós recebemos as peças e o que não passa no teste é devolvido para a fase. Cada fornecedor faz um processo e conseguimos identificar em qual deles deu problema. Quando isso acontece, encaminhamos de volta para o fornecedor.

Você tem hoje uma linha muito grande. Pelo que eu vi na loja, são muitos produtos. Quantos são?

Eu já estou na referência 1.300 .

\section{Então você, nessa marca, já criou 1.300 peças?}

Sim, mas como no passado eu não usava essa referência, então, eu devo ter mais de 2 mil itens.

Como itens, você diz, por exemplo, brinco, colar, pulseira, tudo?

Isso.

\section{Os 1.300 itens estão disponíveis?}

Não, estão no nosso catálogo de referências. Mas, a cada coleção, verificamos o que teve melhor saída ou o que foi mais uma tendência do momento. E a cada coleção resgatamos modelos que vão se tornando clássicos para nós, assim as lojas podem pedir sempre. Muitas vezes, acontece de olharmos uma coleção de três anos atrás e resgatarmos alguns modelos com novas pedras. Sempre fazemos isso.

Então, cerca de quantas peças tem na loja?

Uma média de 3 mil, 2.500. Depende da loja, do fluxo.

Você falou que tem um lado muito intuitivo, age quase como uma coolhunter. Você mesma já capta as tendências. Mas não usa material divulgado em sites de empresas que vendem pesquisas de tendências?

Não. Eu não tenho nenhum. No passado, eu tinha fechado um contrato com um aqui do Brasil mesmo. Mas é como falei: eu sou muito antenada, eu gosto de ler tudo. Tudo o que tem a ver com a minha área, eu vou atrás.

Eu gosto muito de fazer as coisas do jeito que acredito, porque confio muito no meu trabalho. É claro que às vezes tem uma peça ou outra que não vinga, mas a maneira como eu me comunico com as pessoas, com as minhas clientes, sempre deu certo. E sempre que viajo, eu vou às lojas, fico antenada no comportamento das pessoas. Isso me inspira muito. É difícil você me ver assim, parada. Em um momento de tranquilidade, com certeza, eu vou estar fazendo uma pesquisa. Eu sou tipo "a louca da pesquisa".

Você também tem coleções com várias personalidades. Quando faz isso, já está pensando em públicos específicos? Você vai à loja, conversa com as clientes?

A gente sabe que alguns temas não vão conversar com todo mundo, não é? Então, o que eu procuro fazer é como aconteceu com a coleção 
de fevereiro, que criamos com um stylist chamado Yan Acioli. Ele é uma personalidade que veste a Sabrina Sato e outras atrizes. Fechamos essa parceria no Carnaval porque sabiamos que ele vestiria algumas mulheres. Então, havia a chance de ganharmos mídia, exposição. 0 foco eram brincões enormes, do tipo fantasia.

Mas eu não posso também só falar com o público. Então, em todas as minhas coleções, independentemente do tema, eu sempre vou fazer joias mais statement. Sempre vou procurar trazer um básico junto, carregando o tema, claro. É uma maneira que eu vejo de conversar com todos os públicos, da moderninha à mais clássica. Eu procuro levar algum elemento do tema escolhido para a mulher mais clássica, digamos assim.

E para o futuro, em que está pensando? Como vai ser a joia no futuro? Vamos ter joias mais tecnológicas ou você não é muito adepta dessa linguagem?

Eu tenho interesse. Eu vejo essas montagens 3D e aquela joia super high-tech e gosto disso, acho bacana. Porém não as vejo hoje na minha cliente. Claro que tem as supermoderninhas. Mas não consigo enxergar a maioria usando essas peças. Eu acho que está começando, e que também é uma coisa bem artística, conceitual. Como falei, hoje, no meu negócio, eu tenho que estar sempre buscando inovações, um material ou uma tecnologia. E essa busca é um ponto muito importante. Tanto é que um dos fornecedores que fazem as minhas joias também é o dono da fábrica. É um cara viciado em tecnologia. Então, ele tem máquinas com tecnologias ultramodernas que metalizam o metal de tudo quanto é cor. Metalizam a pedra. Uma pedra, que é um cristal, vira quase uma peça de ouro. Existem umas tecnologias com as quais eu fico fascinada e eu tento trazer aos pouquinhos para as minhas coleções. Então eu vou bem de leve.

Mas o que a mulher quer? Ela quer uma peça que traga segurança, que a deixe mais poderosa. Este é o meu objetivo: embelezar, fazer a mulher se sentir feliz com aquilo e tentar sempre surpreender com algo novo, que não tenha sido visto nada parecido.

\section{E sobre o futuro, você comentou que pensa no mercado externo.}

Eu quero transformar a marca em uma referência em acessório no Brasil e no mundo. Vestir grandes personalidades, estar nas principais multimarcas do mundo. Quem sabe outras lojas, além de Barcelona.

\section{Por exemplo, Harrods, Selfridges?}

Yes! Por causa da loja de Barcelona, o grupo Lafayette, de Paris, me procurou e fechamos um contrato. Eles estavam planejando abrir uma Lafayette superluxuosa, glamourosa, em Istambul, em maio. Nós vamos ter um corner Lafayette na Harvey Nichols de Londres. É a primeira. Mas já é um passo, não? Existem algumas lojas que são sonhos de consumo, como a Le Bon Marché e a Colette, em Paris, e a Harrods, em Londres. Acho que se você me perguntasse: qual a cidade em que sonha abrir uma loja? Eu responderia Nova York. Porque acho que Nova York conversa muito com o produto que fazemos. 
E o que mais você almeja ou pensa? Se você tivesse que falar para um estudante de moda, no que ele deveria investir na sua formação?

Eu acho que acreditar no sonho é básico. Mas, às vezes, a pessoa fica muito insegura. Acho que tem que buscar uma identidade própria e acreditar nela, acreditar que pode dar certo. Eu sempre fui assim. Acho que não adianta copiar os outros, ou imitar, ou tentar ser aquilo. Você tem que criar sua própria identidade e correr atrás.

E tem que estar sempre antenado, estudando bastante o mercado. Hoje em dia, eu posso dizer isso. No começo, eu não fiz assim, mas vi a evolução. Meu crescimento aconteceu a partir do momento no qual nos estruturamos, em que buscamos gente capacitada. Hoje, somos uma equipe. Eu não trabalho sozinha. Então, não é um mérito só meu, existe muita gente me ajudando, fazendo a marca crescer, vestindo a camisa.

Os setores estão bem estruturados. Você quer crescer? Ótimo, mas tenha estrutura para isso porque não adianta dar um supersalto e depois ter que voltar atrás. Acho que é mortal assim. Nós vamos passo a passo. Talvez, nesse momento, a gente gostaria muito de estar lá, mas, de repente, essa caminhada mais lenta vai ajudando a chegar lá de uma maneira mais sólida. Acho isto: muito trabalho, não pode ter preguiça, jamais. E amar o que faz. Ter paixão.

Eu posso dizer que trabalho todos os dias feliz. Em feriado às vezes fico nervosa. Porque eu gosto de trabalhar. Sinto falta, quando eu fico muito tempo longe daqui, sinto saudades do meu ateliê.

E eu valorizo todo mundo que está comigo nessa caminhada, porque muitas das pessoas que estão aqui ficam muito mais tempo comigo trabalhando do que nas suas próprias casas. Então, a gente tem uma equipe bacana e eu sinto que está todo mundo abraçado. Justamente por isso se sentem valorizados.

\section{Maria Dolores é o seu nome, não?}

Meu nome tem uma história bacana: eu me chamo Maria Dolores, que é o nome da minha avó. Ela nasceu no dia 9 de dezembro e eu nasci no dia 10. No ano do meu nascimento, a minha avó fez uma festa, e eu quase nasci no dia dela. Minha mãe ficou na festa até meia-noite e depois foi para o hospital. Então, ela resolveu que meu nome não era para ser outro. Minha mãe quis homenagear a minha avó, que é uma das pessoas mais criativas que eu conheci. Acho que absorvi essa criatividade dela, graças a Deus. Ela não está mais entre nós, mas, além do nome, herdei a criatividade. Ela costurava. Tinha muito bom gosto para tudo: para decorar a casa, se vestir. E ela aprendeu sozinha, porque nunca teve orientação ou estudou para isso.

Só que eu sofria muito com esse nome. Não era bullying, porque naquela época não existia isso. Mas, como eu sempre fui muito tímida, eu sofria na escola, porque as professoras erravam o meu nome na chamada. Então, eu era Maria de Lourdes, Maria das Dores, Maria de tudo, menos Maria Dolores. E não é um nome comum, não é um nome que se dá para crianças.

\section{É um nome forte.}

Forte e antigo. Então eu chorava. Queria outro nome e falava para minha mãe: onde já se viu dar esse nome? E eu fiquei tão traumatizada que até na 
faculdade, no dia da minha formatura, eu suava dentro da beca de medo que errassem meu nome, naquele auditório gigante. Hoje em dia, já não tenho mais esse problema, superei. Mas foi longe. Até a minha adolescência eu tinha vergonha. Eu falava Maria. Como é o seu nome? Maria. Sempre Maria.

A minha mãe falava: "Filha, o seu nome é forte, você vai ter muito mais fase adulta do que criança. Todo mundo vai envelhecer. $E$ ai vai chegar, lá no final, e vão ter as Marianas, as Camilas, velhas. E você será a Maria Dolores. Assim, imagino, eu vejo seu nome lá no alto". Minha mãe falava isso. Quando eu montei a minha loja do Crystal, ela viu e ficou até emocionada: "Falei, não falei?".

Fui passar a minha lua de mel em Barcelona. Não, não! Foi quando eu fui fazer um mochilão. Eu tinha 19 anos e fiquei um mês na Europa com a minha irmã, de mochila mesmo, explorando. A gente foi para Barcelona e tinha uma joalheria Maria Dolores. Na Espanha, é um nome comum. Maria Dolores é um nome bem comum. E eu falava: "Nossa, olha só, um dia, quem sabe, eu vou ter a minha loja". Na época, eu nem estava fazendo bijoux.

Assim eu vejo essa coisa da força do pensamento, da energia que você coloca nas palavras. Acredito muito nessas coisas, assim como acredito em intuição, em você seguir o seu sonho, acredito no poder das palavras e dos pensamentos, acredito que você tem que estar em paz e bem equilibrada para conseguir ter êxito nas coisas. Para mim, as coisas funcionam dessa forma. Então, eu tento criar um ambiente ao meu redor que esteja nessa mesma vibração.

\section{Sua equipe no escritório tem quantas pessoas?}

Quinze.

\section{Tem departamentos?}

Aqui é pequenininho. Pretendemos mudar logo porque o espaço ficou minúsculo agora. A Antônia é designer, cria as coleções comigo. A Bruna é do TI, é tecnologia. Ela é responsável pela parte de sistema e consertos, a de serviço. Tem a Tábata, que cuida de compras e faz todos os pedidos. 0 Neto cuida da administração e do financeiro. Temos uma pessoa agora para administrar a internacionalização e procurar novos parceiros. 0 que seria um comercial também. Recepção, comercial, atacado, showroom. É assim. 